\title{
A case-control study on association of nucleotide excision repair polymorphisms and its interaction with environment factors with the susceptibility to non-melanoma skin cancer
}

\author{
Yan-Ling Li ${ }^{1}$, Feng Wei ${ }^{1}$, Yu-Ping Li ${ }^{1}$, Li-Hua Zhang ${ }^{1}$ and Yan-Zhi Bai ${ }^{1}$ \\ ${ }^{1}$ Department of Dermatology, The Second Hospital of Hebei Medical University, Shijiazhuang 050000, Hebei, People's \\ Republic of China \\ Correspondence to: Yan-Ling Li, email: liyanllyy36@163.com \\ Keywords: non-melanoma skin cancer, nucleotide excision repair, single nucleotide polymorphisms, interaction, smoking \\ Received: April 21, $2017 \quad$ Accepted: July 19, $2017 \quad$ Published: September 15, 2017 \\ Copyright: Li et al. This is an open-access article distributed under the terms of the Creative Commons Attribution License 3.0 \\ (CC BY 3.0), which permits unrestricted use, distribution, and reproduction in any medium, provided the original author and source \\ are credited.
}

\section{ABSTRACT}

Aims: To investigate the association of several single nucleotide polymorphisms (SNPs) within nucleotide excision repair (NER) gene and additional gene- gene and gene- smoking interaction with non-melanoma skin cancer (NMSC) risk in a Chinese population.

Methods: A total of 1322 participants (939 males, 383 females) were selected, including 660 NMSC patients and 662 control participants. Generalized multifactor dimensionality reduction (GMDR) was used to screen the best interaction combination among SNPs and smoking. Logistic regression was performed to investigate association between 4 SNPs within NER gene, additional gene- gene and genesmoking interaction on NMSC risk.

Results: NMSC risk was significantly higher in carriers with $G$ allele of rs2228527 than those with AA genotype (AG + GG versus AA), adjusted OR ( $95 \% C I)=1.76$ (1.24-2.37), and higher in carriers with the $G$ allele of rs2228529 than those with AA genotype (AG + GG versus AA), adjusted OR $(95 \% \mathrm{CI})=1.66(1.24-2.13)$. However, we did not find any direct association of the rs4134822 and rs1799793 with NMSC risk after covariates adjustment. GMDR model indicated a significant interaction combination $(p=0.0010)$, including rs2228529 and current smoking. Overall, the cross-validation consistency of this model was $9 / 10$, and the testing accuracy was $60.72 \%$. Current smokers with rs2228529- GA or GG genotype have the highest NMSC risk, compared to never- smokers with rs2228529- AA genotype, OR $(95 \% \mathrm{CI})=\mathbf{2 . 9 2}$ (1.61-4.29).

Conclusions: We found that the G allele of rs2228527 and the G allele of rs2228529 within NER gene, interaction between rs2228529 and current smoking were all associated with increased NMSC risk.

\section{INTRODUCTION}

Non-melanoma skin cancer (NMSC), including squamous cell carcinoma (SCC) and basal cell carcinoma (BCC), ranks the most frequently diagnosed cancer worldwide, and the incidence rates of NMSC has become stabilized and was still increasing [1,2]. Study has indicated that a personal history of NMSC is associated with increased risk of other malignancies [3], and NMSC may be a marker of a cancer-prone phenotype. Several biologic pathways may be disrupted by arsenic exposure, including interfering with the cell cycle activities of p53 or inhibiting base excision repair through reduced DNA ligase III or poly-(ADP-ribose) polymerase activity [46], the most compelling candidate for NMSC among Caucasians is the nucleotide excision repair (NER) 
Table 1: General characteristics for all study participants in NMSC cases and controls

\begin{tabular}{|c|c|c|c|}
\hline Variables & NMSC cases $(n=660)$ & Controls $(n=662)$ & P-values \\
\hline Age (years) & $63.5 \pm 13.6$ & $64.2 \pm 13.1$ & 0.341 \\
\hline Males N (\%) & $464(70.3)$ & $475(71.8)$ & 0.561 \\
\hline $\mathrm{BMI}\left(\mathrm{kg} / \mathrm{m}^{2}\right)$ & $23.4 \pm 9.4$ & $23.1 \pm 9.8$ & 0.570 \\
\hline Current smokers, N (\%) & $255(38.6)$ & $190(28.7)$ & 0.0001 \\
\hline $\begin{array}{l}\text { Current alcohol drinkers, } \mathrm{N} \\
(\%)\end{array}$ & $271(41.1)$ & $290(43.8)$ & 0.312 \\
\hline \multicolumn{4}{|l|}{ Basal cell carcinoma, N (\%) } \\
\hline 1 & $440(66.7)$ & & \\
\hline$>1$ & $220(22.3)$ & & \\
\hline \multicolumn{4}{|l|}{$\begin{array}{l}\text { Squamous cell carcinoma, } \\
\mathrm{N}(\%)\end{array}$} \\
\hline 1 & $403(61.1)$ & & \\
\hline$>1$ & $257(38.9)$ & & \\
\hline $\begin{array}{l}\text { SCC/BCC simultaneously, } \\
\mathrm{N}(\%)\end{array}$ & $356(53.94)$ & & \\
\hline
\end{tabular}

pathway, given the specificity of NER to repair damage from exposure to ambient ultraviolet (UV) radiation. The importance of NER in the etiology of NMSC is well illustrated by xeroderma pigmentosum (XP), a disease in which rare, highly penetrant mutations disrupt the ability of $N E R$ to remove DNA photoproducts, leading to a 1,000-folds increased risk of NMSC [7,8].

DNA repair systems, including $N E R$, base excision repair, mismatch repair, and double-strand break repair, play a critical role in maintaining the stability and integrity of the genome [9, 10]. Previously, some studies [11-15] have reported the association between single nucleotide polymorphism (SNP) in NER genes and NMSC risk, but these studies concluded inconsistent findings. More than $80 \%$ of NMSC incidence could be attributed to ambient UV radiation [16], and several host features such as fair skin, red hair, melanocytic nevi, and family history have also been identified as risk factors [17, 18]. Cigarette smoking was considered as a risk factor for various chronic diseases, however, to date no study focused on the association of NER gene- smoking interaction with NMSC risk. So the aim of this study was to investigate the impact of several SNPs within NER gene, and their additional interaction with smoking on NMSC risk, based on a Chinese population.

\section{RESULTS}

A total of 1322 participants (939 males, 383 females) were selected, including 660 NMSC patients and 662 control participants. The mean age of all participants was $63.9 \pm 12.4$ years. Table 1 shows the general and clinical characteristics for cases and controls participants. The means of age and BMI, distribution of males and current alcohol drinkers were not significantly different between cases and controls. The current smoking rate was higher in cases than controls.

No significant difference in genotype frequencies from the Hardy-Weinberg equilibrium test was noted for any tested SNPs in the controls, all $p$-values were more than 0.05 . The frequency for the $\mathrm{G}$ allele of $\mathrm{rs} 2228527$ was significantly higher in NMSC cases than controls (29.5\% vs $21.4 \%$ ), and similarly, the frequency for the $\mathrm{G}$ allele of rs2228529 was also significantly higher in NMSC cases than controls ( $31.3 \%$ vs $22.1 \%)$. Logistic regression analysis showed that NMSC risk was significantly higher in carriers with $\mathrm{G}$ allele of rs2228527 than those with AA genotype (AG + GG versus AA), adjusted OR (95\%CI) $=1.76$ (1.24-2.37), and higher in carriers with the $G$ allele of rs2228529 than those with AA genotype (AG + $\mathrm{GG}$ versus AA), adjusted OR $(95 \% \mathrm{CI})=1.66(1.24-$ 2.13). However, we did not find any direct association of the rs4134822 and rs1799793 with NMSC risk after covariates adjustment. (Table 2)

We also investigate the synergistic effect among 4 SNPs and current smoking using GMDR model. Table 3 indicated a significant two-locus model $(\mathrm{p}=0.0010)$ involving rs2228529 and current smoking, indicating a potential interaction between rs2228529 and current smoking on NMSC risk. Overall, the cross-validation consistency of this two- locus model was $9 / 10$, and the testing accuracy was $60.72 \%$. We also conducted stratified 
Table 2: Genotype and allele frequencies of 4 SNPs between case and control group

\begin{tabular}{|c|c|c|c|c|c|c|}
\hline \multirow[t]{2}{*}{ SNPs } & \multirow{2}{*}{$\begin{array}{l}\text { Genotypes } \\
\text { and alleles }\end{array}$} & \multicolumn{2}{|c|}{ Frequencies N (\%) } & \multirow[t]{2}{*}{ OR $(95 \% C I) *$} & \multirow[t]{2}{*}{ p-values } & \multirow{2}{*}{$\begin{array}{c}P \text { - values for } \mathrm{HWE} \\
\text { test in controls }\end{array}$} \\
\hline & & Controls $(n=662)$ & Cases $(n=660)$ & & & \\
\hline \multicolumn{7}{|c|}{ rs2228527 } \\
\hline \multicolumn{7}{|c|}{ Co-dominant } \\
\hline & $\mathrm{AA}$ & $410(61.9)$ & $332(50.3)$ & 1.00 (ref) & & \multirow[t]{7}{*}{0.722} \\
\hline & $\mathrm{AG}$ & $220(33.2)$ & $266(40.3)$ & $1.58(1.19-2.04)$ & 0.001 & \\
\hline & GG & $32(4.8)$ & $62(9.4)$ & $2.01(1.37-2.76)$ & $<0.001$ & \\
\hline & Dominant & & & & & \\
\hline & $\mathrm{AA}$ & $410(61.9)$ & $332(50.3)$ & 1.00 (ref) & & \\
\hline & $\mathrm{AG}+\mathrm{GG}$ & $252(38.1)$ & 328 (49.7) & $1.76(1.24-2.37)$ & $<0.001$ & \\
\hline & Allele, G (\%) & $284(21.4)$ & $390(29.5)$ & & & \\
\hline \multicolumn{7}{|c|}{ rs2228529 } \\
\hline & \multicolumn{6}{|l|}{ Co-dominant } \\
\hline & AA & 408 (61.6) & $319(48.2)$ & 1.00 (ref) & & \multirow[t]{7}{*}{0.138} \\
\hline & $\mathrm{AG}$ & $215(32.5)$ & $272(41.1)$ & $1.52(1.14-1.99)$ & 0.0012 & \\
\hline & GG & $39(5.9)$ & $71(10.7)$ & $1.91(1.42-2.46)$ & $<0.001$ & \\
\hline & Dominant & & & & & \\
\hline & $\mathrm{AA}$ & 408 (61.6) & $319(48.2)$ & 1.00 (ref) & & \\
\hline & $\mathrm{AG}+\mathrm{GG}$ & $254(38.4)$ & $343(51.8)$ & $1.66(1.24-2.13)$ & $<0.001$ & \\
\hline & Allele, G (\%) & $293(22.1)$ & $414(31.3)$ & & & \\
\hline \multicolumn{7}{|c|}{ rs4134822 } \\
\hline & \multicolumn{6}{|l|}{ Co-dominant } \\
\hline & GG & $587(88.7)$ & $594(89.7)$ & 1.00 (ref) & & \multirow[t]{4}{*}{0.122} \\
\hline & GA & $75(11.3)$ & $68(10.3)$ & $1.12(0.74-1.54)$ & 0.624 & \\
\hline & $\mathrm{AA}$ & $0(0)$ & $0(0)$ & & & \\
\hline & Allele, A (\%) & $75(5.7)$ & $68(5.1)$ & & & \\
\hline \multicolumn{7}{|c|}{ rs1799793 } \\
\hline & \multicolumn{6}{|l|}{ Co-dominant } \\
\hline & $\mathrm{AA}$ & $379(57.2)$ & $339(51.4)$ & 1.00 (ref) & & 0.127 \\
\hline & $\mathrm{AG}$ & $234(35.3)$ & $255(38.6)$ & $1.20(0.79-1.74)$ & 0.579 & \\
\hline & GG & $49(7.4)$ & $66(10.0)$ & $1.41(0.82-2.06)$ & 0.706 & \\
\hline & \multicolumn{6}{|l|}{ Dominant } \\
\hline & $\mathrm{AA}$ & $379(57.2)$ & $339(51.4)$ & 1.00 (ref) & & \\
\hline & $\mathrm{AG}+\mathrm{GG}$ & $283(42.7)$ & $321(48.6)$ & $1.22(0.80-1.84)$ & 0.628 & \\
\hline & Allele, G (\%) & $332(25.1)$ & $387(29.3)$ & & & \\
\hline
\end{tabular}

*Adjusted for gender, age, BMI, smoking and alcohol drinking.

analysis for rs2228529 and current smoking using logistic regression. We found that current smokers with rs2228529- GA or GG genotype have the highest NMSC risk, compared to never- smokers with rs2228529- AA genotype, OR $(95 \% \mathrm{CI})=2.92(1.61-4.29)$, after covariates adjustment (Table 4). 
Table 3: GMDR analysis on the best gene- gene and gene-smoking interaction models

\begin{tabular}{|c|c|c|c|c|}
\hline Locus no & Best combination & $\begin{array}{c}\text { Cross-validation } \\
\text { consistency }\end{array}$ & Testing accuracy & p-values \\
\hline \multicolumn{5}{|c|}{ Gene- gene interactions* } \\
\hline 2 & rs 2228529 rs2228527 & $8 / 10$ & 0.5399 & 0.0547 \\
\hline 3 & rs2228529 rs2228527 rs1799793 & $7 / 10$ & 0.5399 & 0.1719 \\
\hline 4 & rs2228529 rs2228527 rs1799793 rs4134822 & $5 / 10$ & 0.4958 & 0.3770 \\
\hline \multicolumn{5}{|c|}{ Gene- smoking interactions* } \\
\hline 2 & rs2228529 current smoking & $9 / 10$ & 0.6072 & 0.0010 \\
\hline 3 & rs2228529 rs2228527 current smoking & $7 / 10$ & 0.4958 & 0.3770 \\
\hline 4 & $\begin{array}{c}\text { rs2228529 rs2228527 rs1799793 current } \\
\text { smoking }\end{array}$ & $6 / 10$ & 0.4958 & 0.4258 \\
\hline 5 & $\begin{array}{c}\text { rs2228529 rs2228527 rs1799793 rs4134822 } \\
\text { current smoking }\end{array}$ & $5 / 10$ & 0.5399 & 0.6230 \\
\hline
\end{tabular}

*Adjusted for gender, age, BMI, smoking and alcohol drinking.

**Adjusted for gender, age, BMI and alcohol drinking.

Table 4: Stratified analysis for gene-smoking interaction by using logistic regression

\begin{tabular}{lccc}
\hline rs2228529 & Current smoking & OR (95\% CI) & P-values \\
\hline $\mathrm{AA}$ & No & 1.00 & - \\
$\mathrm{AG}+\mathrm{GG}$ & No & $1.30(1.04-1.72)$ & 0.026 \\
$\mathrm{AA}$ & Yes & $1.45(1.14-1.89)$ & $<0.001$ \\
$\mathrm{AG}+\mathrm{GG}$ & Yes & $2.92(1.61-4.29)$ & $<0.001$ \\
Overall $p$ - value for interaction= 0.0036 & & & \\
\hline
\end{tabular}

*Adjusted for gender, age, BMI and alcohol drinking.

\section{DISCUSSION}

In this study, we found that both the $\mathrm{G}$ allele of ERCC6- rs2228527 and the G allele of ERCC6rs2228529were significantly associated with increased NMSC risk in a sample of the Chinese Han population. NMSC risks were significantly higher in carriers with $\mathrm{G}$ allele of ERCC6- rs2228527 than those with AA genotype, and higher in carriers with $\mathrm{G}$ allele of ERCC6rs2228529 than those with AA genotype. However, we did not find any direct association of the rs4134822 and rs1799793 with NMSC risk after covariates adjustment. Previously, many studies have focused on the association between NER gene and some other diseases, including prostate cancer [19], gastric cancer [20] and thyroid cancer [21]. Several studies [11-15] were also performed on association between SNPs within $N E R$ gene and NMSC risks, but the limited number for these articles could not concluded a consistent result on this association, and could not clarify the mechanism between NER gene and NMSC susceptibility. Some studies support a non- significantly association between these variants and decreased risk of NMSC [14, 22], whereas others have found non- significant increases in NMSC risk [11, 23]. Previously, just one study [15] has reported evidence on the association between either rs2228527 or rs2228529 and NMSC, a thorough evaluation of $N E R$ gene variants revealed associations between two functional ERCC6 SNPs and NMSC, which to our knowledge have been reported firstly, and the increased risk was consistent among both men and women. The rs2228529 SNP falls within a highly conserved ubiquitin-binding domain in ERCC6 that is necessary for the transcription-coupled repair branch of $N E R$ [24]. a population-based study in New Hampshire with nearly 900 cases of BCC and 700 of SCC, observed by Miller et al [13] indicated a 15-25\% decreased risk of either BCC or SCC among those with the XPA A23G (rs 1800975) polymorphism. Another study also indicated that a $20 \%$ decreased risk of SCC and $10 \%$ decreased risk of BCC among those carrying variant forms of both $X P D$ Lys751Gln and Asp312Asn [12], after adjusting for age, 
Table 5: Probe and primer sequences for 4 SNPs used for genotyping

\begin{tabular}{|c|c|c|c|c|}
\hline SNP ID & Gene & Chromosome & $\begin{array}{l}\text { Functional } \\
\text { consequence }\end{array}$ & Primer/probe sequences \\
\hline rs2228527 & $\begin{array}{c}\text { ERCC6 } \\
\text { Arg1213Gly }\end{array}$ & $10: 49470323$ & Missense & $\begin{array}{c}\text { 5'-AAAGCCTAAGAACTCTAAGCATTGC[A/G] } \\
\text { GAGACGCCAAGTTTGAAGGAACTCG-3' }\end{array}$ \\
\hline rs2228529 & $\begin{array}{c}\text { ERCC6 } \\
\text { Gln1413Arg }\end{array}$ & $10: 49459059$ & Missense & $\begin{array}{c}\text { 5'- TTAGAAAGTGAAAGCGGGCACCTGC }[\mathrm{A} / \mathrm{G}] \\
\text { GGAAGCTTCTGCCCTGCTGCCCACC-3' }\end{array}$ \\
\hline rs4134822 & $\begin{array}{l}X A B 2 / X P A \\
\text { Val126Ile }\end{array}$ & 19:7627389 & Missense & $\begin{array}{c}\text { 5'- CCAGTTCCTCATGGACCAGGGGCGC[A/G] } \\
\text { TCACACACACCCGCCGCACCTTCGA-3' }\end{array}$ \\
\hline rs 1799793 & $\begin{array}{c}\text { XPD } \\
\text { Asp312Asn }\end{array}$ & $19: 45364001$ & $\begin{array}{l}\text { Missense, nc } \\
\text { transcript variant }\end{array}$ & $\begin{array}{c}\text { F: 5'-CAGCTCATCTCTCCGCAGGATCAA-3' } \\
\text { R: 5'-GTCGGGGCTCACCCTGCAGCACTTCCT-3' }\end{array}$ \\
\hline
\end{tabular}

sex, skin pigmentation, and number of severe sunburns. Han et al [25] suggested a roughly $20 \%$ decreased risk for XPD Asp312Asn (rs1799793), whereas neither was associated with BCC.

NMSC susceptibility could be influenced by both genetic and environment factors, and previously several environmental factors associated with NMSC were reported, such as smoking, which was an important modifiable factor for NMSC [26, 27]. In current study, the smoking rate was higher in NMSC cases than controls, so we not only investigated gene- gene interaction on NMSC risk, but also gene- environment interaction between SNPs and smoking. We found a significant interaction between rs2228529 and current smoking on NMSC risk, current smokers with rs2228529- GA or GG genotype have the highest NMSC risk, compared to never- smokers with rs2228529- AA genotype. Smoking and NER SNPs appears to be the important risk factor for NMSC. Therefore, it is plausible that the coexistence of smoking and minor allele of rs2228529 contribute to the highest NMSC risk.

There several limitations in our study. Firstly, more participants should be included in this study, and the results obtained in this study should be checked by future studies with larger sample size. Secondly, some others environmental risk factors should be included in the gene- environment interaction detection, such as BMI, which was a new related factor for NMSC. Thirdly, sex differences on this association should be investigated in the future studies. Thirdly, the controls were selected from a population without any type of cancer who received physical examination in the hospital, but they would not be representative of the general population, so the selection bias may exist in this study. Lastly, the data on ultraviolet radiation (UVR) exposure was not collected in the investigation, so we could not exclude the influenced of UVR on the results.

In conclusion, we found that the $G$ allele of rs2228527 and the G allele of rs2228529within NER gene, interaction between rs2228529 and current smoking were all associated with increased NMSC risk.

\section{MATERIALS AND METHODS}

\section{Subjects}

The study consisted of 1322 participants (939 males, 383 females), including 660 NMSC patients and 662 control participants. The mean age of all participants was $63.9 \pm 12.4$ years. Cases were defined as patients, aged 18 years and older, diagnosed with a histologically confirmed basal or squamous cell carcinoma between April 2010 and July 2015 and were recruited from the Second Hospital of Hebei Medical University. The controls were randomly selected from a population without any type of cancer, who received physical examination in our hospital and $1: 1$ matched to cases on the basis of age ( \pm 3 years) and sex. Individuals recruited to the control group had no previous history or family history of cancer. Both the NMSC cases and controls were unrelated Han Chinese population. Questionnaire investigation was conducted for all participants, and data on demographic information, clinical and biochemical index and life style for all participants were obtained. Body weight, height were measured. Blood samples were collected from each participant in the morning after at least 8 hours of fasting. Informed consent was obtained from all participants.

\section{Genomic DNA extraction and genotyping}

The NCBI database (http://www.ncbi.nlm.nih. gov/projects/SNP) is used for SNPs selection according to the following methods: 1) located in a gene fragment that could have functional effects; 2) MAF more than $5 \%$; 3) previously reported associations with NMSC, but is not well studied. In this study, four SNPs within $N E R$ gene were selected for genotyping, including: ERCC6- rs2228529 (Arg1213Gly), ERCC6- rs2228527 (Gln1413Arg), XPD- rs1799793 (Asp312Asn) and $X A B 2 / X P A$ - rs4134822 (Val126Ile). Genomic DNA from participants was extracted from EDTA-treated whole blood, using the DNA Blood Mini Kit (Qiagen, Hilden, Germany) according to the manufacturer's instructions. 
Genotyping for rs2228529, rs2228527 and rs4134822 were detected by Taqman fluorescence probe. Probe sequences of all SNPs were shown in Table 5. ABI Prism7000 software and allelic discrimination procedure was used for genotyping of fore-mentioned three SNPs. Probes for the 3 SNPs were listed in Table 5. A $25 \mu$ l reaction mixture including $1.50 \mathrm{ul}$ SNP Genotyping Assays (20×), 12.25 $\mu$ l Genotyping Master Mix $(2 \times)$, 20ng DNA, and the conditions were as follows: initial denaturation for $10 \mathrm{~min}$ and $93^{\circ} \mathrm{C}$, denaturation for $15 \mathrm{~s}$ and $90^{\circ} \mathrm{C}$, annealing and extension for $120 \mathrm{~s}$ and $65^{\circ} \mathrm{C}, 60$ cycles. Genotyping for rs 1799793 was performed by polymerase chain reaction (PCR) restriction fragment length polymorphism (PCRRELP) method. The primers and PCR conditions are shown in Table 1. The PCR conditions were as follows: $95^{\circ} \mathrm{C}$ for $5 \mathrm{~min} ; 30$ cycles of $95^{\circ} \mathrm{C}$ for $30 \mathrm{~s}, 60^{\circ} \mathrm{C}$ for $30 \mathrm{~s}$, and $72^{\circ} \mathrm{C}$ for $30 \mathrm{~s}$; and a final extension step of $72^{\circ} \mathrm{C}$ for $10 \mathrm{~min}$. Genotyping results were confirmed by randomly assaying $10 \%$ of the original specimens for replication to exclude genotyping errors. There were no discrepancies between genotypes determined in duplicate.

\section{Statistical analysis}

Categorical variables were presented as absolute values and percentages, and continuous variables were expressed as means \pm standard deviations (SD). Student's t test was used to compare continuous variables, while Chi-square test was used to compare categorical variables between cases and controls. Hardy-Weinberg equilibrium (HWE) examination was used by SNPstats (http://bioinfo. iconcologia.net/SNPstats). Generalized multifactor dimensionality reduction (GMDR) was used to screen the best interaction combination among SNPs and current smoking. Logistic regression was performed to investigate the impact of 4 SNPs within NER gene on NMSC risk, and additional stratified analysis for gene- current smoking interaction on NMSC risk. Two sided test with $P<0.05$ was considered statistically significant.

\section{ACKNOWLEDGMENTS}

The writing of this paper was supported by the Second Hospital of Hebei Medical University. We thank all the partners and staffs who help us in the process of this study.

\section{CONFLICTS OF INTEREST}

None.

\section{FUNDING}

None.

\section{REFERENCES}

1. Rogers HW, Weinstock MA, Feldman SR, Coldiron BM. Incidence estimate of nonmelanoma skin cancer (keratinocyte carcinomas) in the U.S. population, 2012. JAMA Dermatol. 2015; 151:1081-6.

2. Deady S, Sharp L, Comber H. Increasing skin cancer incidence in young, affluent, urban populations: a challenge for prevention. Br J Dermatol. 2014; 171:324-31.

3. Wheless L, Black J, Alberg AJ. Nonmelanoma skin cancer and the risk of second primary cancers: a systematic review. Cancer Epidemiol Biomarkers Prev. 2010; 19:1686-95.

4. Li JH, Rossman TG. Comutagenesis of sodium arsenite with ultraviolet radiation in Chinese hamster V79 cells. Biol Met. 1991; 4:197-200.

5. Vogt BL, Rossman TG. Effects of arsenite on p53, p21 and cyclin D expression in normal human fibroblasts- a possible mechanism for arsenite's comutagenicity. Mutat Res. 2001; 478:159-68.

6. Yager JW, Wiencke JK. Inhibition of poly (ADP-ribose) polymerase by arsenite. Mutat Res. 1997; 386:345-51.

7. Kraemer KH, Patronas NJ, Schiffmann R, Brooks BP, Tamura D, DiGiovanna JJ. Xeroderma pigmentosum, Trichothiodystrophy, and Cockayne syndrome: a complex genotype- phenotype relationship. Neuroscience. 2007; 145:1388-96.

8. Rass K, Reichrath J. UV damage and DNA repair in malignant melanoma and nonmelanoma skin cancer. Adv Exp Med Biol. 2008; 624:162-78.

9. Lindahl T, Wood RD. Quality control by DNA repair. Science. 1999; 286:1897-905.

10. Goode EL, Ulrich CM, Potter JD. Polymorphisms in DNA repair genes and associations with cancer risk. Cancer Epidemiol Biomarkers Prev. 2002; 11:1513-30.

11. Vogel U, Hedayati M, Dybdahl M, Grossman L, Nexø BA. Polymorphisms of the DNA repair gene XPD: correlations with risk of basal cell carcinoma revisited. Carcinogenesis. 2001; 22:899-904.

12. Applebaum KM, Karagas MR, Hunter DJ, Catalano PJ, Byler SH, Morris S, Nelson HH. Polymorphisms in nucleotide excision repair genes, arsenic exposure, and nonmelanoma skin cancer in New Hampshire. Environ Health Perspect. 2007; 115:1231-6.

13. Miller KL, Karagas MR, Kraft P, Hunter DJ, Catalano PJ, Byler SH, Nelson HH. XPA, haplotypes, and risk of basal and squamous cell carcinoma. Carcinogenesis. 2006; 27:1670-5.

14. Lovatt T, Alldersea J, Lear JT, Hoban PR, Ramachandran S, Fryer AA, Smith AG, Strange RC. Polymorphism in the nuclear excision repair gene ERCC2/XPD: association between an exon 6- exon 10 haplotype and susceptibility to cutaneous basal cell carcinoma. Hum Mutat. 2005; 25:353-9.

15. Wheless L, Kistner-Griffin E, Jorgensen TJ, Ruczinski I, Berthier-Schaad Y, Kessing B, Hoffman-Bolton J, Francis L, 
Shugart YY, Strickland PT, Kao WH, Alani RM, Smith MW, Alberg AJ. A community-based study of nucleotide excision repair polymorphisms in relation to the risk of non-melanoma skin cancer. J Invest Dermatol. 2012; 132:1354-62.

16. Xiang F, Lucas $R$, Hales $S$, Neale R. Incidence of nonmelanoma skin cancer in relation to ambient UV radiation in white populations, 1978-2012: empirical relationships. JAMA Dermatol. 2014; 150:1063-71.

17. Linares MA, Zakaria A, Nizran P. Skin Cancer. Prim Care. 2015; 42:645-59.

18. Wu S, Han J, Laden F, Qureshi AA. Long-term ultraviolet flux, other potential risk factors, and skin cancer risk: a cohort study. Cancer Epidemiol Biomarkers Prev. 2014; 23:1080-9.

19. Wang M, Li Q, Gu C, Zhu Y, Yang Y, Wang J, Jin L, He J, Ye D, Wei Q. Polymorphisms in nucleotide excision repair genes and risk of primary prostate cancer in Chinese Han populations. Oncotarget. 2017; 8:24362-71. https://doi. org/10.18632/oncotarget.13848.

20. Zheng DL, Tang GD, Chen YN, Zhang T, Qin MB. Genetic variability of ERCC1 and ERCC2 genes involved in the nucleotide excision repair pathway influences the treatment outcome of gastric cancer. Genet Mol Res. 2016; 15.

21. Santos LS, Gomes BC, Gouveia R, Silva SN, Azevedo AP, Camacho V, Manita I, Gil OM, Ferreira TC, Limbert E, Rueff J, Gaspar JF. The role of CCNH Val270Ala (rs2230641) and other nucleotide excision repair polymorphisms in individual susceptibility to welldifferentiated thyroid cancer. Oncol Rep. 2013; 30:2458-66.
22. Vogel U, Olsen A, Wallin H, Overvad K, Tjønneland A, Nexø BA. Effect of polymorphisms in XPD, RAI, ASE-1 and ERCC1 on the risk of basal cell carcinoma among Caucasians after age 50. Cancer Detect Prev. 2005; 29:209-14.

23. Yin J, Rockenbauer E, Hedayati M, Jacobsen NR, Vogel U, Grossman L, Bolund L, Nexø BA. Multiple single nucleotide polymorphisms on human chromosome 19q13.2-3 associate with risk of basal cell carcinoma. Cancer Epidemiol Biomarkers Prev. 2002; 11:1449-53.

24. Anindya R, Mari PO, Kristensen U, Kool H, Giglia-Mari G, Mullenders LH, Fousteri M, Vermeulen W, Egly JM. A ubiquitin-binding domain in Cockayne syndrome B required for transcription-coupled nucleotide excision repair. Mol Cell. 2010; 38:637-48.

25. Han J, Colditz GA, Liu JS, Hunter DJ. Genetic variation in XPD, sun exposure, and risk of skin cancer. Cancer Epidemiol Biomarkers Prev. 2005; 14:1539-44.

26. Silverberg JI, Ratner D. Associations of non-melanoma skin cancer and melanoma, extra-cutaneous cancers and smoking in adults: a US population-based study. J Eur Acad Dermatol Venereol. 2015; 29:1389-97.

27. Rollison DE, Iannacone MR, Messina JL, Glass LF, Giuliano AR, Roetzheim RG, Cherpelis BS, Fenske NA, Jonathan KA. Case-control study of smoking and nonmelanoma skin cancer. Cancer Causes Control. 2012; 23:245-54. 